\title{
Natural and man-induced evolutionary shifts in the birds of some Cuban cays
}

\author{
ORLANDO H. GARRIDO
}

\begin{abstract}
Summary
Evidence from described subspecies and sightings and collection of distinct but undescribed forms suggests that the cays fringing Cuba have harboured populations of birds that represent their earliest invaders, but that, with the advent of man (and in particular the recent development of causeways between the mainland and the cays), these relictual, endemic populations have been outcompeted or genetically swamped by more recently evolved subspecies from the main island.
\end{abstract}

La evidencia que arroja la descripción de nuevas subespecies, así como observaciones y especímenes colectados de formas aún no descritas, sugiere que la orla de cayos que rodea la isla de Cuba ha albergado poblaciones de aves que representan los primeros colonizadores. Esto, junto a la llegada del hombre (y particularmente el desarrollo reciente de pedraplenes que unen los cayos con la isla), ha provocado que estas poblaciones relictuales endémicas hayan sído desplazadas o genéticamente asimiladas por subespecies de la isla de Cuba que evolucionaron en tiempos más recientes.

\section{Introduction}

Cuba and its satellite islands consist of some 4,159 cays including the major Isla de la Juventud (formerly Isle of Pines) and several large cays that well merit designation as islands, such as Coco, Romano, Guajaba, Sabinal, Largo del Sur and Cantiles. Coco, Romano, Guajaba and Sabinal belong to the Sabana-Camagüey Archipelago, and the others, including Isla de la Juventud, to the Los Canarreos Archipelago. The major archipelagos, indicated in Figure 1, are: Las Coloradas (north of the province of Pinar del Río), Sabana-Camagüey (stretching along the central northern part of Cuba), Jardines de la Reina (south of Camagüey province), Los Canarreos (south of the provinces of Havana and Matanzas), and the Cayos de San Felipe, which actually constitute the western section of Los Canarreos (south of the province of Pinar del Río).

Some subspecies of birds from these archipelagos have been described: the Great Lizard-cuckoo Saurothera merlini santamariae, Cuban Green Woodpecker Xiphidiopicus percussus cocoensis and Zapata Sparrow Torreornis inexpectata varonai from Sabana-Camagüey; Greater Antillean Pewee Contopus caribaeus florentinoi and C. c. nerlyi from Jardines de la Reina; C. c. morenoi, X. p. gloriae, West Indian Red-bellied Woodpecker Melanerpes superciliaris florentinoi, Cuban Vireo Vireo gundlachi magnus, Greater Antillean Grackle Quiscalus niger caribaeus and Tawnyshouldered Blackbird Agelaius humeralis scopolus from Los Canarreos; V. g. sanfelipensis, C. c. sanfelipensis and M. s. sanfelipensis from Cayos de San Felipe.

Beside these described forms, other populations have been mentioned in the literature that seem to be morphologically distinct and which may therefore 


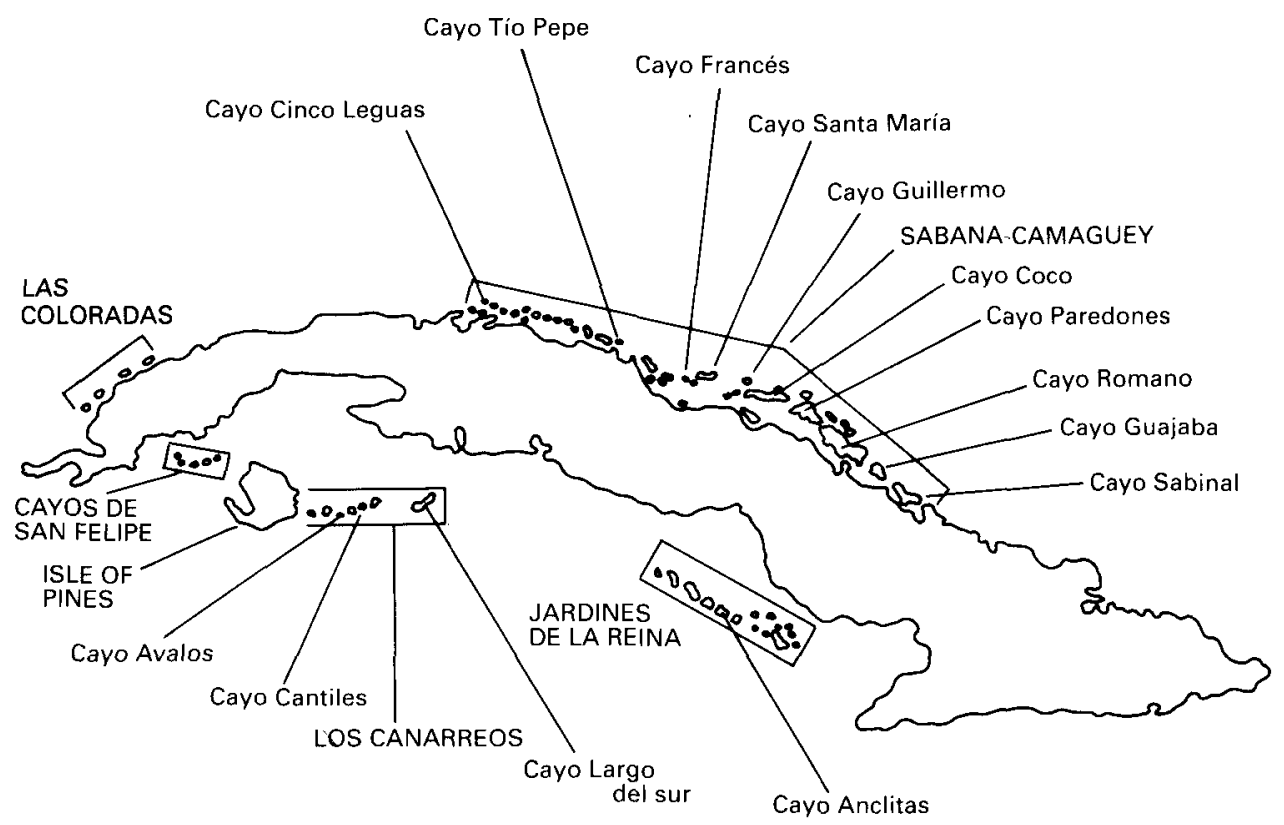

Figure 1. Cuba and its archipelagos, with the position of the cays mentioned in the text.

merit subspecific rank, for example the populations of Contopus caribaeus, Vireo gundlachi, Xiphidiopicus percussus (Cayos Cinco Leguas and Tío Pepe) from Sabana-Camagüey; $X$. percussus and Turdus plumbeus from Jardines de la Reina; and Melanerpes superciliaris from Los Canarreos (Cayo Avalos) (Garrido et al. 1986, Kirkconnell and Estrada ms).

Since none of the islets and cays that comprise these archipelagos has substantial elevation, and practically none rises more than a few metres above sea level, it is obvious that bird and reptile life was settled for good on them only after the last glaciostatic movement. That means that none of these populations should be older than 11,000 years, probably only 8 , ooo or even 6,000 years or less in some cases. However, this period of time has been long enough to develop races not only of birds but also of reptiles, especially from the genera Ameiva and Leiocephalus, and notably on the same cays as the described races of birds (see Schwartz 1959, Schwartz and McCoy 1970).

The populations on these cays must naturally be subject to periodic reinforcement through invasions from mainland Cuba. The processes by which subspeciation takes place in spite of this phenomenon are not well understood; but once subspeciation has occurred, new invasions by the same species must represent a threat rather than a reinforcement. Over the years I have been accumulating evidence to support the view that many morphologically distinct forms, representing the original invaders of the cays, have been steadily disappearing through the genetic swamping of recent invaders from mainland dispersals. Since the local populations (the endemic relicts) are quite reduced in numbers, as few as 25 generations of cross-breeding with recent invaders are likely to be sufficient to produce a drastic change in the phenotype of the animals. 


\section{Sabana-Camagüey}

When I first collected a specimen of Xiphidiopicus at Cayo Tío Pepe very different from normal in coloration (brownish abrasion tinge), I assumed that the specimen was aberrant (Garrido 1971b). Then, after seeing no less than five other individuals (two of them forming a pair) at Cayo Cinco Leguas (both islands being at the westernmost end of the Sabana-Camagüey Archipelago), I realized that they could not be mutants. I wrote to James Bond about it, and he replied that they might be members of a different subspecies. If so, they were certainly in a minority as far as individuals were concerned, since I observed many specimens of Xiphidiopicus on these cays that had the appearance of the mainland form. It is now some 25 years since I collected that first problematic Xiphidiopicus on Tío Pepe, and it would be most interesting to see how many individuals of the "abrasion type" it belonged to currently remain there and on Cinco Leguas.

This same scenario appears to apply to Xiphidiopicus percussus on Cayo Coco and Cayo Paredones, in the central-eastern sector of the archipelago. Several years ago, when Nerly Lorenzo brought me two adult specimens from Cayo Coco, I described them as cocoensis, as they were smaller and darker than mainland populations (Garrido 1978a). However, more recently Arturo Kirkconnell, during his trips to the northern cays of Camagüey, began bringing me specimens not only from Cayo Coco, but from Cayo Guillermo (I also already had available others from Cayo Sabinal). To my surprise, all these birds were very similar in size, pattern and coloration to mainland populations of nominate percussus. This urgently required re-examination and remeasurement of the type and paratype of cocoensis, duly undertaken by Kirkconnell; however, they were just as detailed in the original description.

The situation remained unclear until Kirkconnell himself brought back four specimens from Cayo Guillermo in 1988. Two of them were similar in size, pattern and coloration to the type and paratype of cocoensis; the two others to all other specimens from Cayo Coco, Guillermo, Sabinal and mainland Cuba (and most closely to some specimens from the northern coast of Camagüey province). Cayo Guillermo is even more isolated than Cayo Coco, and this means that perhaps reinvasions from other nearby cays or the mainland are more difficult than reinvasions of the major cays closer to the coast.

The same situation applies to Vireo gundlachi and Contopus caribaeus from Cayo Francés, Santa María, Guillermo and others, in the centre of the archipelago (Garrido 1973). In the case of the vireo, sometimes birds clearly assignable either to the eastern mainland race orientalis or to the western nominate gundlachi were found together, but with one phenotype in the minority (see Garrido 1971a). It is probable that during Gundlach's time, because there had been no man-induced changes on the cays, all birds were phenotypically gundlachi; now they are more like orientalis. In the case of the pewee, only one race was known from the mainland, but two different phenotypes, one darker, were found together in some of the cays (Garrido 1973). Buden and Olson (1989) note that the Contopus in the easternmost part of Cuba probably merit subspecific rank, being much brighter and less grey.

A similar problem with the pewee was recently encountered at Cayo 
Paredones, off Cayo Romano. In 1988 Kirkconnell, while studying migration on this cay, brought to the museum, among other local resident birds, one specimen of Contopus very different from the Cuban mainland populations. We thought it might be a different subspecies of this bird, so in 1989 he returned to the cay and collected a series of eight specimens. To our surprise, only one of them closely resembled the 1988 original (and two others that he observed in life); three were identical to the mainland population, and the rest had clearly intermediate stages of plumage. It would thus appear that the dark race represents the original resident population of the cay (probably proceeding from an earlier dispersal), while the lighter birds represent a more recent invasion from other populations on the mainland via the larger ("island") cays of the archipelago.

\section{Jardines de la Reina}

Similar developments may be expected in Jardines de la Reina in due course, although some of its more isolated cays may be free from reinvasions for longer, and the older, endemic stock may thus persist for a corresponding period. However, these cays have not been explored recently, and most available material is that noted by Buden and Olson (1989).

The two described subspecies of Contopus caribaeus within this archipelago, nerlyi from Cayo Las Cruces (Garrido 1978b) and florentinoi from Cayo Anclitas (Regalado Ruíz 1977), may represent a double invasion. One was probably the original resident, and the other a more recent invader. Buden and Olson's (1989) synonymizing of the two may, however, be appropriate, although further examination of specimens is first desirable.

\section{Los Canarreos}

When I first found and described as new Melanerpes superciliaris florentinoi on Cayo Largo, its population was restricted to one end of the cay in palm (yuraguano Coccotrynax sp.) country (Garrido 1966). Bond (1956) had failed to find this bird during five days on the cay, presumably as he did not visit the area concerned. Several years later, I returned there, and to my surprise I found an individual in the western part of the cay, where the species had not previously been recorded. I collected the bird and found it indistinguishable from nominate populations (probably a straggler from Cuba or Cayo Cantiles, where no subspecifically distinct birds or reptiles have evolved). I have no idea about the current situation of florentinoi, but with the transformation and development of the cay, notably for tourism, I doubt very much that it has survived.

In this regard a specimen of Melanerpes superciliaris from Cayo Avalos referred to by Buden and Olson (1989) is noteworthy. They found that this specimen differed from both nominate superciliaris and the race murceus from the Isle of Pines. It too may represent a relict population with a history perhaps not very different from that of $M$. s. florentinoi.

The situation of the grackle Quiscalus niger again reveals a process of displacement of one race by another. The smaller race with a bluish metallic sheen, $Q$. $n$. caribaeus, is the resident form in Los Canarreos Archipelago, Isla de la Juventud, 
the western tip of the Península de Guanahacabibes, and in the northern coastal cays as far as Cayo Francés and Cayo Santa María in the Sabana-Camagüey Archipelago; however, the populations found at Cayo Coco, Guillermo, Romano and Paredones are instead assignable to the mainland race gundlachi on the basis of their greater size and their violet metallic sheen. Although they do not attain the maximum size of gundlachi, they fully fall within the standard measurements of this race. This must be a result of interbreeding with the smaller, resident caribaeus in past times. Buden and Olson (1989) postulate that gundlachi originated somewhere in the eastern part of the island and began to spread west, displacing the smaller caribaeus, forcing it into its current isolated, relictual populations. The situation in these northern cays of Camagüey agrees with this interpretation. Moreover, nearly 40 years ago Bond (1956) had already discovered that the cays from Jardines de la Reina, closer to the coast, possessed populations more like gundlachi, while the rest of the cays harboured populations of caribaeus.

\section{Conclusion}

The future of the endemic, relict populations of the Cuban cays does not appear to be bright. While it is, of course, true that what I have documented here is a seemingly natural process of invasion, absorption and extinction, the activities of man may have been instrumental in abetting these developments. The reduction of habitat on certain cays would cause a corresponding reduction in numbers of endemic forms, leaving them all the more exposed to the influence of genetic swamping by invaders; or the modification of habitats may facilitate the establishment of invading mainland birds on cays; or both.

Certainly now, several cays face serious modification through tourist development and others are being connected to the mainland and to each other through the construction of "pedraplenes" (causeways), which will be a major blow to the isolation their endemic wildlife has enjoyed. At present one such bridge is being built to link Cayo Coco to the mainland, and three others are being planned, including one to Los Canarreos.

The virtual extinction of the endemic birdlife (and indeed the herpetofauna also) of the Cuban cays seems inevitable, and may take as little as 50 years. There is therefore a clear need to intensify research on these forms partly to determine whether any human intervention on their behalf is possible, and partly at least to establish a full record of their diversity (including of course their DNA) before they disappear forever.

\section{Acknowledgement}

I am most grateful to Dr Lester L. Short for translating this paper into English.

\section{References}

Bond, J. (1956) Check-list of the birds of the West Indies. Philadelphia: Academy of Natural Sciences of Philadelphia.

Buden, D. W. and Olson, S. L. (1989) The avifauna of the cayerias of southern Cuba, with 
the ornithological results of the Paul Bartsch expedition of 1930. Smithsonian Contrib. Zool. 477.

Garrido, O. H. (1986) Nueva subespecie del Carpintero Jabado, Centurus superciliaris (Aves: Picidae), para Cuba. Poeyana Ser. A., 29.

Garrido, O. H. (1971a) Una nueva subespecie del Vireo gundlachii (Aves: Vireonidae) para Cuba. Poeyana 81: 1-8.

Garrido, O. H. (1971b) Variación del género monotípico Xiphidiopicus (Aves: Picidae) en Cuba. Poeyana 83: 1-9.

Garrido, O. H. (1973) Anfibios, reptiles y aves del Archipiélago de Sabana-Camagüey. Torreia (NS) 27: 1-72.

Garrido, O. H. (1978a) Nueva subespecie de Carpintero Verde (Aves: Picidae) para Cayo Coco, Cuba. Informe Científico Técnico 67: 1-6.

Garrido, O. H. (1978b) Nuevo Bobito Chico (Aves: Tyrannidae) para Cuba. Informe Científico Técnico 68: $1-6$.

Garrido, O. H. (ms) Los vertebrados terrestres del Archipiélago de los Canarreos.

Garrido, O. H., Estrada, A. R. and Llanes, A. (1986) Anfibios, reptiles y aves de Cayo Guajaba, Archipiélago de Sabana-Camagüey, Cuba. Poeyana 328: 1-34.

Kirkconnell, A. and Estrada, R. (ms) Aves y reptiles de Cayo Paredones, Archipiélago de Sabana-Camagüey, Cuba.

Regalado Ruíz, P. (1977) Nueva subespecie de Contopus caribaeus. Rev. Forestal 1-2: 37-40 [for uncertainty of this reference see Buden and Olson (1989: 32)].

Regalado Ruíz, P. (1981) El género Torreornis (Aves: Fringillidae), descripción de una nueva subespecie de Cayo Coco, Cuba. Centro Agricola 2: 87-112.

Schwartz, A. (1959) Variation in lizards of the Leiocephalus cubensis complex in Cuba and the Isla de Pinos. Bull. Florida State Mus., Biol. Sci. 4(4): 97-143.

Schwartz, A. and McCoy, C. J. (1970) A systematic review of Ameiva auberi Cocteau (Reptilia, Teiidae) in Cuba and the Bahamas. Ann. Carnegie Mus. 41: 45-117.

ORLANDO H. GARRIDO

Museo de Historia Natural "Felipe Poey", La Habana, Cuba 